\title{
Manacled to Identity: Cosmopolitanism, Class, and 'The Culture Concept' in Stephen Crane
}

\author{
Michael J. Collins \\ University of Kent, UK
}

This article begins with a close reading of Stephen Crane's short story 'Manacled' from 1900, which situates this rarely considered short work within the context of contemporary debates about realism. I then proceed to argue that many of the debates raised by the tale have an afterlife in our own era of American literary studies, which has frequently focused on questions of 'identity' and 'culture' in its reading of realism and naturalism to the exclusion of the importance of cosmopolitan discourses of diffusion and exchange across national borders. I then offer a brief reading of Crane's novel George's Mother, which follows Walter Benn Michaels in suggesting that the recent critical attention paid to particularities of cultural difference in American studies have come to conflate ideas of class and social position with ideas of culture in ways that have ultimately obscured the presence of genuine historical inequalities in US society. In order to challenge this critical commonplace, I situate Crane's work within a history of transatlantic cosmopolitanism associated with the ideas of Franz Boas and Matthew Arnold to demonstrate the ways in which Crane's narratives sought out an experience of the universal within their treatments of the particular.

Keywords Stephen Crane, Matthew Arnold, Franz Boas, George's Mother, 'Manacled', Maggie, print culture, transatlantic, cosmopolitanism, aestheticism

In May I900 the American author and journalist Stephen Crane published the short story 'Manacled' in the London magazine The Argosy. In several senses Crane was the archetypal expatriate American author of the later modernist era: writing, publishing, and settling in England at a time when he was facing increasing hostility in the US press for the bohemian character of his work and his decadent, nonconformist lifestyle. Crane's circle of friends and associates in fin de siècle Great Britain reads like a checklist of some of the most successful and important writers of the age. Henry James and Joseph Conrad were frequent visitors to his home at Brede in East 
Sussex, Rudyard Kipling was approached to complete his final, unfinished novel The O'Ruddy, H.G. Wells wrote a glowing obituary of Crane in the August I90o issue of The North American Review, and Arnold Bennett and Ford Madox Ford were emphatic in their praise. Whereas his US critical notices after The Red Badge of Courage (I895) had been increasingly disparaging, British critics generally were more favourable across the whole of his career. For this reason the decision to publish 'Manacled' first in the London Argosy, rather than with the New York syndicates that had previously carried his short fiction, was in keeping with the broad trajectory of Crane's career in the final years of the I89os. Indeed, Crane did not settle in his home country and they would not readily claim him for their own. By I895, cosmopolitan mobility became Crane's personal and artistic raison d'être. After leaving Asbury Park, New Jersey as a teenager, Crane lived in New York, Florida, Greece, Cuba, and Britain, seldom settling for long before a new journalistic commission moved him on to pastures new.

At one time The Argosy had been a leading light in the Victorian periodical scene and had appealed to the middle classes through a careful pairing of the lush, preRaphaelite inspired illustrations of William Small with fictional content that shuttled between popular categories of the sensational and sentimental. But, by I900, The Argosy had begun to face financial difficulties and a declining readership. In I87I the magazine had been sold to the famous publishers Richard Bentley \& Sons, whose prior successes with the publication of Charles Dickens, Edward Bulwer-Lytton, James Fenimore Cooper, Frances Trollope, and other major authors in cheap, 'standard', single-volume editions seemed to suggest that the publishing house would be well placed to help the periodical capture the rising, literate, lower-middle-class readership of late-Victorian Britain. ${ }^{\mathrm{I}}$ However, the move left the magazine awkwardly placed in a literary marketplace that was becoming increasingly bifurcated and diversified along the lines of class and culture and, in I90I, it folded.

In a cruel and ironic parallel with the fate of the publication in which his story appeared, by 1900 Crane also was facing severely declining health and fortunes. A month after the publication of 'Manacled' in London, the thirty-year-old Crane died of a lung haemorrhage at a health spa in the German town of Badenweiler. Indeed, it is tempting to read 'Manacled' biographically as both a prescient foreshadowing of his own fate and a more general allegory of authorial, artistic, and critical decline. Set in the shabby 'Theatre Nouveau [...] upon a street which was not of the first importance' (Crane, I984: I29I), in a transatlantic city space that is deliberately devoid of identifying features, the story describes the last moments in the life of an actor who is forced to perform a dull, artistically unambitious melodrama for a 'pitying audience' (I29I) in which 'real horses drunk real water out of real buckets [...] dragging a real wagon off stage' (I29I). When the theatre catches fire, the unnamed actor finds that he is unable to escape because the crowd's demand for verisimilitude has led to the use of 'real handcuffs on his wrists and real anklets on his ankles' (I29I). Like The Argosy itself, the actor is unable to balance adequately between a residual demand for sentimental melodrama and a new trend for realism that was coming to dominate late-nineteenth-century transatlantic literary culture. In a neat joke Crane even transfers this problem onto the theatre itself, which is called Nonveau but performs material that is distinctly passé, even ancien. 
In 'Manacled', Crane exaggerates the 'realness' of the fictional play so as to probe the limits of realism as an authorial practice and satirize its attempts to represent the truth of the world 'out there' through fiction. By presenting the reader with a vision of the dangerous effects of stasis, Crane argues that realistic fictions frequently abandoned any ethical imperatives which may have been attendant upon the writer in favour of textualizing their subjects as the products of a particular temporal and spatial locus. In so doing, the author also dramatizes the very process that would prompt a crisis for The Argosy magazine: the emergence of increasingly fixed cultural hierarchies in America and Britain organized around class position and artistic taste. The warning is clear. Fixed identities and modes of representation are a dangerous trap. Crane's setting for 'Manacled' foregrounds the importance of art and culture to his narrative, while his insistence on the status of the theatre as 'not of the first importance' flags up the relation between the story and vexed questions of taste and class. Lawrence Levine has suggested that, more than any other space, by the late nineteenth century the theatre had become a clear marker of the establishment of a hierarchy of culture - a location of societal bifurcation along the lines of class (Levine, I990: 88). More than this, Crane cleverly couches these cultural hierarchies in the language of geology in order to reflect his own creative moment, when the demand for realism in representation and what George Stocking, Mark Pittenger, and others have diagnosed as the dominant Lamarckian and Darwinian theories of evolution and heredity in Gilded Age thought were attaching increasing importance to the role of environment in the shaping of social manners and behaviours. ${ }^{2}$ As the fire rips through the theatre, Crane notes how 'the building hummed and shook; it was like a glade which holds some bellowing cataract of the mountains. Most of the people killed on the stairs clutched their play-bills in their hands as if they had resolved to save them at all costs' (I984: I29I). Not only can the actor not move because the manacles demanded by the audience's taste for realism physically inhibit him from doing so, but the playgoers die fixed in attitudes precipitated by their cultural choices, which, since the Lamarckian bent of popular discussions of behaviour saw one's culture as a product of one's environment, trap the individual in an inexorable feedback loop. Importantly, 'the people killed on the stairs' clutch neither at each other for comfort, nor at the railings or doors for safety, but at 'their play-bills', as if identifying their cultural status was more significant than preserving their own lives. In this passage, Crane generates connections between processes of artistic consumption, geographical deep time, death, and the will to 'resolve' or 'save' in a way that seems to render the actions of the individuals historical in a manner that is reminiscent of anthropological and geological practices of observation and classification.

Crane's use of the term 'resolve' is particularly interesting in this context. The word exhibits a peculiar ambivalence: simultaneously connoting an individual's will (their resolve) and, in an age of the photographic image, both the process by which a picture emerges on paper (to resolve) and the 'resolution', i.e. the quality of the visual rendering of that object. The word therefore 'naturalizes' the individual within a cultural and environmental context, collapsing the distinction between individual subjectivity and the act of viewing: the first and third person. This is picked up in the story through a repeated technique of confusing the human and non-human and the living and non-living. As the conflagration grows, the narrator remarks how 
'the thunder of the fire-lions made the theatre have a palsy' (I293). The elemental 'fire' is transformed into 'lions' and the material space of the theatre seems to have the distinctly nervous, organic response of 'a palsy'. The narrative of the story consistently jumps between third-person descriptions of events and images and the internal, subjective thoughts of the protagonist in a way that embeds character within context, implying that forces seemingly beyond their control have begun to overwhelm the individual. As the actor succumbs to the effects of the fire, he is described as feeling 'very cool, delightfully cool' (I293). Like the figures on the stairs, he seems perversely to freeze to death in the heart of a raging fire - the subject of an irredeemable geographical and mental inertia.

Following the American Civil War, and the challenges it posed to the older perceived certainties of antebellum nationalism, writers sought new sources of authority in which to locate and ground narratives of contemporary experience. Brad Evans has noted that this new search for authority produced a boom of interest in 'ethnographic enquiries' (Evans, 2005: 83) into folklore and local colour that allowed the scientific classification and survey work of groups such as the American Geological Survey and The Bureau of American Ethnology (BAE) to find popular readerships. This ethnographical survey work began at precisely the moment that the broadly sentimental narrative of national unity began to decline in the face of a developing modernity. In effect, a version of nationalism organized around collective feeling and sympathy could not survive the rise of corporate capitalism and the fracturing of the nation, what William Dean Howells called (borrowing from Shakespeare) 'a hazard of new fortunes'. Instead of national unity, American social scientists began to cultivate an image of American national experience organized around diversity. Such an agenda became all the more complex when class came to be seen in the same terms. The contemporary trend for slum writing, reform journalism, and urban exposés, best exemplified by Jacob Riis' bestselling phototext How the Other Half Lives: Studies Among the Tenements of New York ([I890] 20I0) and Charles Loring Brace's infamous The Dangerous Classes of New York (I872), contributed to a sense that class position resembled the forms of cultural and racial difference studied by the ethnologists. The sense that there were distinctive, transparent differences between the classes was apparent in the title of Riis' work, which otherized the behaviour and lifestyles of the urban poor to render them acceptable subjects for the exercise of reform. As Mark Pittenger has claimed, the pursuit of difference in Gilded Age and Progressive Era writing led to the 'belief that workers and the poor were somehow fundamentally different - a strange breed in classless America' (Pittenger, I997: 28). While the romantic and transcendentalist mind of the antebellum era had largely imagined authority over culture as lying in the hands of 'representative men' (to borrow Emerson's phrase), with unique aesthetic and visionary capacities to capture the 'universal' patterns of historical development and shape experience according to their own will, the turn of attention towards environmental factors in science and art made culture into a mere adaptation to context and placed new limits upon human flourishing. Culture became less something to be acquired in the pursuit of a better life for the individual and more a reflection of the situation of that individual in relation to place. One did not accumulate culture as one had in previous times. Instead, like Louis Althusser's diagnosis of ideology, it was something 
always already present in the life and actions of individuals and groups (Althusser, I984).

Keith Gandal notes in The Virtues of the Vicious (1997) that the increasing attention paid to environment and 'culture' in realist and naturalist art radically affected the capacity of narratives of class to represent the possibility of upward social mobility. 'The traditional novel of the poor was centred around a moral struggle and transformation', writes Gandal, 'usually involved a battle to resist the bad influences of the slums and the pressures of physical misery [...] slum characters are often mercifully saved from participating in their surroundings' (I997: 45). Whereas the preferred character of sentimental and romantic art had been the lower-middle-class mechanic - a figure of potential whose skills and wits afforded them the capacity to 'overcome' the physical constraints of their environment and generate sympathy across the lines of class and status - by the time of works like Crane's Maggie (I893) or Frank Norris's McTeague (I899) environment seemed to be everything. These figures now seldom triumphed over their world, but were, instead, products of it, who attempted to survive and learn to adapt to the expectations of their culture.

By the I880s, many authors and readers had begun to define authorial skill in social-scientific and bio-evolutionary terms through the capacity to realistically render the particularities of group-based differences and their adaptation to environment (Barrish, 200I; Elliott, 2002). For this practice to operate, realists had to be sufficiently versed in the particularities of dialect and behaviour specific to regions and locales. In Crane's case this frequently resulted in critics associating him with the people he represented in his fiction. Within a climate that profiled people according to the environments they inhabited and the classes to which they seemed outwardly to belong, Crane was often the subject of a remarkable double standard. At once lauded for his attention to specific details and hauled before the courts for 'slumming it' among the drunks and prostitutes of New York's notorious Tenderloin District, Crane could not find an easy home in the Gilded Age USA. At the same time, however, Crane's New York bohemianism became one of the main attractions for readers of his fiction. But, for the cosmopolitan Crane, simple correspondences between environment and behaviour were dangerous and depreciated the value of the author as a transmitter and mobilizer of culture across the wider Atlantic world. By removing identifying features and the revealing specificities from his description of the theatre fire, such as its precise location or the specific names or 'races' of the individuals involved, Crane in 'Manacled' destabilizes the presumably fixed correspondences between locales and cultural or classed regimes of behaviour demanded by both reformist slum literature and ethnographical surveys. Furthermore, by publishing the tale (like most of his other more overtly 'American' works) first in England, Crane deploys the reach of transatlantic print to put culture into dynamic circulation, cultivating a sense of Anglo-American similarity organized around universal, transatlantic class inequalities that disrupts the political project of objectification along the lines of 'culture', 'race', 'national identity', and geography. 'Manacled' therefore reveals a cosmopolitan sensibility in Crane's work, which, I would argue, has been inadequately captured by critical practices that have the nation as their central focal point. This is not to imply that Crane wholly abandoned particulars in favour of blandly universal forms of narrative, but rather that Crane's forms of regionalism, realism, and specification were always filtered through a print culture which was implicitly, even intentionally, transatlantic. 
In his own moment this cosmopolitanism was finding its outlets in the burgeoning transnational Aesthetic Arts Movement, whose publishing and artistic centres in New York, Paris, and London deployed their localities less to highlight the particular exceptionalism of their cities, and more in order to cultivate a particularly bohemian international form of urban chic. In 'Manacled', Crane (the ultimate bohemian author) very deliberately engaged with this movement and its international style by centring the action of his own story around the distinctly Parisian-sounding 'Theatre Nouveau'. When the narrator talks of the near musical 'hum of the flames' (Crane, I984: I292), or offers heavily alliterative, near-purple descriptions of how 'smoke, filled with sparks sweeping on spiral courses, rolled thickly' (I292), Crane courts an abstraction that is clearly more reminiscent of the decadent, cosmopolitan style of artists like James McNeill Whistler, Walter Sickert, or Charles Baudelaire than it is of the robust realism of William Dean Howells, Hamlin Garland, or The Ashcan School painters. Brad Evans has noted how Maggie (I893), 'while ostensibly about the ghetto, seems even more to be about blowing apart the contrived staging of reform journalism [...] with an exercise in pure aestheticism — "the girl, Maggie, blossomed in a mud pile"' (Evans, 2005: I4I). What makes Crane's work translatable across national borders therefore is its refusal to attach to culture the qualities of an especially unique or distinctive character. The confusion of simulacra generated by a sentimental melodrama being played in a French-named theatre in an unknown city space produces the effect of aesthetic dissonance. Or rather, at the very moment that he risks objectifying a culture through textualization, he places that text in circulation by adopting a distinctly transatlantic aesthetic posture. In this way, Crane's art objects (his stories) deliberately abandon their status as being representative of a particular locale in order to become something more like the collective inherence of a wider Atlantic civilization. In his time, Crane was criticized for his refusal to, as an article called 'Mr Crane's Sketches' in the 27 April I898 edition of Westminster Gazette put it, 'give [...] us the complete novel which some day or other we all expect of him' (in Monteiro, 2009: I69). However, I would argue that, in adopting the sketch form as a model in his novels and short stories, Crane was deliberately generating a version of literary realism that was more easily diffusible internationally and deploying a fleeting lightness of touch to serve as an antidote to the thickly descriptive tendencies of ethnographic literature.

Rather than being a simple meditation on decline, therefore, 'Manacled' speaks more generally to Crane's literary project of challenging the sense of stasis evoked by the turn towards environmental and cultural determinism in realist literature through a cosmopolitan, transnational narrative that highlights how individuals and cultures are seldom fixed by context but can diffuse and translate across borders. More particularly, the story is the final example of Crane's career-long meditation upon the complex interrelationships between realism as an authorial practice that 'valorized the firsthand observation and textual representation of group-based difference' (Elliott, 2002: xiii) and class, identity, and competing, nascent understandings of the meaning of 'culture' in the transatlantic world that he had begun in his early New York sketches and Maggie. Recently, scholars such as Michael Elliott and others have begun to investigate how 'the conflict between different concepts of culture - one that relies upon ideas of static irreducible difference and another that offers the possibility of universal cultural development — was central to the debate surrounding 
the nature of literature in the age of realism, as well as to the products of literature' (Elliott, 2002: 48). Adding to this growing body of scholarship, I suggest here that Crane's work is engaged in an important discussion about the various meanings and values attached to the term 'culture', which was the subject of renewed attention in European and American intellectual discourse in this period. For this purpose it is beneficial to situate Crane alongside two other key intellectuals of the late nineteenthcentury transatlantic world - Matthew Arnold and Franz Boas - whose radically distinct, but I would argue, equally cosmopolitan, notions of 'culture' were directed towards the same implicit goal of freeing individuals from the tyranny of class and cultural stasis implied by the turn towards environmental dominance in understandings of human behaviour.

\section{Crane, Boas, Arnold, and American studies}

In late-nineteenth-century cosmopolitan cities like Crane's New York, the ideas of the British poet and sage Matthew Arnold had considerable purchase in American and transatlantic literature. In his important collection of essays entitled Culture and Anarchy from I869, and later during his I884 lecturing tour of the USA, Arnold defined 'culture' as a universal, progressive, and acquirable ideal directed towards 'the pursuit of perfection' (Arnold, 2006: 52) that was, at least partly, synonymous with the values of a social order he called 'civilization'. For Arnold, 'culture' was the struggle of beauty and truth against the harsh, 'Philistine' world of laissez-faire capitalism and utilitarian governmental oversight, a continual process of 'growing and becoming' (36) that developed from within the individual and extended outwards to shape the wider social world. More significantly though, 'culture' for Arnold was decidedly not an 'engine of social distinction' and did not 'separate its holder, like a badge or title, from other people' (33). What characterized Arnoldian 'culture' was a certain form of romantic discontentment with the 'machinery' of the status quo, including its class and social distinctions: 'a dissatisfaction which is of the highest possible value in stemming the common tide of men's thoughts in a wealthy and industrial community, and which saves the future [...] from being vulgarized' (39). Rather than cultivating a state of rather passive conditioning by environment as Lamarckian adaptationists like the American Geological Survey and BAE argued, Arnoldian 'civilization' was intently acquisitive, attentive, dynamic, omnivorous, and forward-looking. For Arnold, culture was the opposite of bland liberal utilitarianism and might even serve as the basis for a new politics of inclusion.

From our contemporary perspective, Arnold's vision of cultural perfectionism and use of the terms 'civilization' and 'Philistinism' appears at best snobbish and at worst a possible vehicle for a certain Anglo-Saxon supremacist discourse. However, Arnoldian culture also offered the late nineteenth century a useful language for critiquing one's own national or local scene by liberating thought systems from their immediate context and situating them in a new order of meaning. Read in this way, Arnold's romantic vision of the possibility of a universal, collective inheritance of 'high culture' does not necessarily conflict with another conceptualization that is often presented as its inverse: the emergent, pluralistic, relativistic, and ethnographic 'culture concept' of the American-German-Jewish émigré anthropologist Boas. Indeed, lauding Boas 
for his relativism and denigrating Arnold for a racist particularism and chauvinism which he vehemently rejected have become marks of faith among the liberal-left in American literary studies. This is because, while the Arnoldian definition drew from the Anglo-American traditions of John Stuart Mill and Ralph Waldo Emerson to argue that 'culture' was synonymous with the progressive values of social and personal 'cultivation', Boas' education in the German anti-Enlightenment thought of figures such as Herder and von Humboldt led to his stressing the particularities and pluralities of group behaviours in a manner that speaks more directly to our contemporary interest in questions of 'identity' and 'diversity'. However, in contradistinction to pre-existing narratives of human behaviour put forward by the American Geological Survey and BAE — which had used regressive Lamarckian evolutionary hierarchies to argue that cultural development occurred solely within separate racialized and particularized groups (a principle known as 'independent invention' ${ }^{3}$ ) Boas argued that humanity was essentially dynamic and shaped its cultures through constant borrowing. In fact, George Stocking has suggested: 'for Boas, man was essentially rather uninventive, but his creativity was expressed in his imaginative manipulation and reinterpretation of elements given to him by his cultural tradition, or borrowed from other cultural traditions' (Stocking, I982: 226). In one of his most famous pieces of fieldwork among a variety of tribes on either side of the Bering Strait - The Jesup North Pacific Expedition of I897 - Boas sought to test out existing theories of the autonomy of cultural groups against his vision of culture as shaped by processes of exchange. In the introduction to the report Boas wrote:

The peculiar interest that attaches to this region is founded on the fact that here the Old World and the New come into close contact. The geographical conditions favor migration along the coast-line, and exchange of culture. Have such migrations, has such exchange of culture, taken place? This question is of great interest theoretically [...] it is necessary to investigate with thoroughness all possible lines and areas of contact [...] (Boas in Stocking, 1982: 108-09)

By foregrounding the importance of 'contact' rather than the coherence of cultural traditions within autonomous tribal groups, Boas forced anthropology to consider the role played by global currents of political and social history over and above a romantic fixation on the defining 'genius' or character of a people.

Reading Crane in light of these radical, late-nineteenth-century, cosmopolitan discourses allows us to interpret the horrifying image of stasis in 'Manacled' as being indicative of the author's concern that the realist practice with which he had become associated in fiction frequently fixed class within a liberal, identitarian framework we have come to call 'cultural particularism', contributing to a conception of the immutability of differences generated by wealth disparity that ironically served to reinforce a political conservatism which he avowedly opposed. Indeed, Crane's observation concerning people's desire to cling to their culture unto death in 'Manacled' has distinct resonances in our own era of American literary studies. Walter Benn Michaels has argued that the very concept of 'cultural relativism', of which Boas was among the earliest advocates in America (which was such an important tool for confronting the racist, nationalist, and xenophobic particularisms of his own era), has re-emerged in American studies through our collective 'commit[ment] to [a] principle of identity essentialism' (Michaels, I995: I40) that is actually distinctly un-Boasian. Specifically, 
in valorizing 'culture' as a pluralistic category that helps to cultivate 'diversity' of thought and action within a representative democracy, without paying sufficient attention to the question of diffusion, transmission, and change that occupied Boas, Crane, and Arnold, we have replaced one version of essentialism (biological or racial determinism) with another (cultural or identitarian determinism). Michaels has suggested that embedded within contemporary theories of multiculturalism is the potentially dangerous assumption that one's systems of thought and action are both conditioned by, and representative of, one's culture. In this way, we have come to live out the legacy not of Boas, but of the Lamarckian BAE in our attempts to locate within texts representative values that might allow us an access point to the beliefs and behaviours of particular diversified groups which emerged historically within certain local areas. While this is important for the preservation of difference, it serves us little in developing a sound critique of class, since, unlike the other categories, class is something that we would do well to abolish. Possessing a sense of self-esteem within a distinct 'working-class culture', after all, is scant compensation for the reduction in potential that comes with a lack of resources. The acquisition of a sense of self-worth, which Keith Gandal has highlighted as being Crane's primary concern in his fictions of the Bowery, ultimately is a conservative process that cultivates an attitudinal barrier that exonerates a profoundly unequal status quo: social habits and behaviours of an autonomous, undiffused social group. In drawing attention to the awkward conflation of social class with habitus then, Crane can be seen to critique an exceptionalist American narrative that frequently elevates the notion of one's irrefutable right to a 'culture', while obfuscating the presence of genuine, longstanding, transnational inequalities in shifting focus from unfair economic practices to ethnographical questions of taste and behaviour.

Michaels' observation that class as a category always has existed in uneasy relation with the contemporary valorization of cultural diversity organized around the traditional triumvirate of postmodern representation (race, gender, and sexuality) is particularly pertinent for approaching Gilded Age realism. Amy Kaplan's The Social Construction of American Realism (I988) typifies the critical approach taken by much American literary scholarship to reading realism that I have described above. In this work, Kaplan adopted a Foucauldian perspective to argue: 'class differences struck the realists less as a problem of social justice than as a problem of representation. They were less concerned with the accuracy of portraying "the other half" than with the problem of representing an interdependent society composed of competing and seemingly mutually exclusive realities' (Kaplan, I988: II).

In highlighting how the realists falsified coherence through discourse in order to combat the 'mutually exclusive' nature of realities in the late nineteenth century and foregrounding postmodern questions of representation, Kaplan's work has contributed to an understanding of realism that aims to trace a clear genealogy from nineteenth-century writing to twentieth-century multiculturalism. Brad Evans recently has noted that, while the idea of 'culture' is treated with considerable suspicion in contemporary anthropology, 'cultural theorists working in the humanities, and particularly Americanists, have not been [...] eager to engage in a similar critique' (Evans, 2005: I7). I would argue then that the commitment to a liberal version of multiculturalism frequently has resulted in a reduction of the capacity of pre-existing American studies methodologies to accurately account for economic inequalities that 
are the products of distinctly transnational processes of exchange and trade. As Charles Briggs has noted: 'rethinking multiculturalism can help us unmask how the liberal claim that everyone is equally entitled to their own culture is being used to disguise the creation of inequalities within and between nations' (2005: 78). Reading Crane's work about the lower classes as harbingers of twentieth-century multicultural purviews rooted in what Briggs has described as a nationalistic, 'liberal program for confronting racism that celebrates autonomous cultural worlds' (76) therefore foreshortens its capacity to speak more generally for Atlantic modernity. Crane's fiction often benefits from an approach that more accurately reflects the moment when an emergent Boasian relativism existed alongside the Arnoldian, humanist conception of 'culture'. This can be seen in an earlier work of Crane's - George's Mother - in which Arnoldian perfectionism is presented as a more appropriate model for the treatment of class in fiction, because unlike a relativized understanding of social behaviours that highlighted the plurality of 'autonomous cultural worlds', Arnold's vision opened up the possibility of social mobility. In other words, Crane's novel critiques the liberal search for 'identity' as a politically conservative process that seeks out a static conception of selfhood rooted in one's affiliation with the behaviours of a particular, autonomous, relativized group.

\section{George's Mother and the culture habit}

George's Mother dramatizes the effects of conflating class with a theory of culture grounded in the specifics of place by using a conflict between a boy and his mother over the former's incipient alcoholism. When it was first published, the novel was read as a classic temperance tale of the kind that was common to late-nineteenthcentury audiences where a 'fundamentalist morality' was juxtaposed with 'the cynical, braggart amorality of the street' (Murphy, I98I: 88). Reviewers of the novel often read it in this light as a didactic tale of the importance of avoiding the daemon drink. One reviewer from the Philadelphia Evening Bulletin even went so far as to suggest that the story was for children and 'should receive a place on the fat shelves of our Sunday-school libraries' (Monteiro, 2009: 7I). Readings in our own era have tended to follow the lead of Maxwell Geismar in offering liberal, psychoanalytic interpretations of the novel as a 'tragic-comic oedipal love relationship' (I953: 94) centred around George's search for individual and group identity to separate him from the control of his overbearing mother. Such readings focus upon George's essential difference from his mother and his flawed quest for self-identity and a 'culture' of his own (in the partial Boasian sense I have discussed above) among the hard-drinking 'roughs' of New York's Lower East Side.

As George Kelcey becomes more and more dependent upon alcohol he comes to more accurately reflect what are shown to be the demands and 'secrets' of his 'culture': 'He understood that drink was essential to joy, to the coveted position of a man of the world and of the streets. The saloons contained the mystery of the street for him' (Crane, I984: 258). Kelcey's alcoholism is presented as a form of ritualized initiation into the secrets and patterns of behaviour of the Lower East Side that is peculiarly reminiscent of Lewis Henry Morgan's study of initiations among the Iroquois League. These produce in him feelings of 'self-esteem' that temporarily compensate for his rejection by his 'dream-woman' (237) Maggie Johnson. Kelcey's 
gradual development of 'brotherly feeling' towards his fellow drinkers is expressed by Crane in distinctly scornful ethnographic terms. As the young men drink they recite stories and sing repetitious songs, while Crane's rendering of the effects of alcohol upon the pronunciation of their already idiosyncratic street dialect produces a radical effect of alienation on the part of the reader, as if trying to interpret another language: 'G'l'm'n, I lovsh girl! I ain' drunker'n yeh all are!' (247). When another uninitiated individual enters the private drinking room at the pub where they are stationed, Crane writes: 'The men sprang instantly to their feet. They were ready to throttle any invader of their island' (228). In their efforts to locate for themselves a sense of attachment to a culture or set of localized behaviours, the drinkers have abandoned the Boasian dream of circulation in exchange for a dynamic of in-group and out-group. Rather than being products of a cosmopolitan city space then, Crane ironically presents the street gangs as oddly and self-consciously separated from modernity, behaving in a way that situates them outside of their Gilded Age moment and within the circumscribed space of a 'primitive' tribal other described by contemporary ethnographic and reform literature.

Readers who have sought to differentiate George from his mother often have missed Crane's suggestions in the text of how ultimately similar the two characters come to be. This is because what really motivates Crane in the novel is exploring the danger of fixed identities and the abandonment of hope among the fin de siecle working class. Consequently, the novel can be read as being a symbolic enactment of how new definitions of culture in the nineteenth century, which highlight the significance of environment and context in shaping experience, ultimately limited and reduced the worldviews of individuals. Crane approaches this topic by means of a discussion of the idea of 'habit'. The author charts the course of George's alcohol addiction alongside that of his mother, whose increasingly fervent religiosity becomes increasingly habitual. Indeed, the words 'habit' or 'habitual' appear frequently throughout the novel. Chapter VI opens thus:

The little old woman habitually discouraged all outbursts of youthful vanity upon the part of her son. She feared that he would think too much of himself, and she knew that nothing could do more harm. Great self-esteem was always passive, she thought, and if he grew to regard his qualities of mind as forming a dazzling constellation, he would tranquilly sit still and nor do those wonders she expected of him. (234)

In this passage, Crane introduces several key themes of the novel: 'habit', the passivity of 'self-esteem', and the desire of human flourishing. In the novel, the establishment of a sense of identity in George produces a staggering passivity. When confronted by his mother about losing his job after frequently failing to turn up, George responds with hostility: 'Ah, whatter yeh givin us? Is this all I git when I come home f'm, being fired? Anybody 'ud think it was my fault. I couldn't help it' (266). In locating an identity for himself among the alcoholics of the Lower East Side, George has begun to passively enact the expectations of his 'culture'. Unlike her son, George's mother is defined not by her emotional connection to the fellow denizens of the tenement, but by her continued struggle towards transcendence and the cultivation of an aesthetic and moral beauty that is distinctly Arnoldian. When Crane first introduces the 'little old woman' she is in the 'flurry of battle [...] through the cloud of dust or steam one could see the thin figure dealing mighty blows. Always her way seemed 
best. Her broom was continually poised, lance-wise, at dust demons' (2I9). The narrator's tone here is richly ironic, even sarcastic. Yet, the nature of the struggle is clear and provides a counterpoint to the 'passive' indoctrination into a group identity and 'self-esteem' undergone by George. For Matthew Arnold 'cultivation' or the pursuit of cultural achievement was an ongoing, strenuous effort of will characterized by disenchantment and disaffection rather than positive feelings of attachment or self-esteem. But what ultimately scuppers this process in George's Mother is that the actions she associates with the improvement of her life and environment become habitual and mechanical - the very opposite of Arnold's vision of progressive development. Crane captures this aesthetically by repeating the same scene, in which Mrs Kelcey enters George's room and attempts to rouse him to action, several times.

George's Mother appeared at a moment when the role of habit and habituation in the shaping of cultural behaviours was a hotly-debated topic in popular and social-scientific journals. The pragmatist philosopher Charles Sanders Peirce had first introduced this idea in an essay entitled 'How to Make Our Ideas Clear' in the January I878 edition of Popular Science Monthly. In this essay, and an earlier piece entitled 'The Fixation of Belief', Peirce argued that one's perception of what constitutes truth or value is largely conditioned by the relation of a new idea or sense impression to a pre-existing conception. 'The essence of belief', wrote Peirce, 'is the establishment of a habit; and different beliefs are distinguished by the different modes of action to which they give rise' (Peirce, I878). For Peirce, one's ideas are fixed by their pre-existing modes of action, which are designed to appease doubts and uncertainties: 'If beliefs do not differ in this respect, if they appease the same doubt by producing the same rule of action, then no mere differences in the manner of consciousness of them can make them different beliefs' (I878). Similar to the Lamarckian theory of culture's emphasis on the shaping role of environment, Peircean pragmatism turned all concepts into the search for habits or fixed modes of being that allowed us to 'appease the irritation of doubt'. For Crane, however, such an 'appeasement of doubt' signalled the potential triumph of one's context over individual will. In its place, the author advocates a more dynamic, fluid, and aesthetic approach to life that abandons the search for a fixed identity in order to pursue a cosmopolitan search for cultural improvement.

Crane's cosmopolitan radicalism then is of a strange breed. At once conservative in its insistence upon the importance of cultural development and human flourishing, and progressive in its refusal of ethno-racial and socioeconomic particularities, Crane brought a strong vein of internationalism and class critique to an American scene that often seemed to possess an ideological blindness to the dangers of the liberal search for identity. In order to challenge the ethics of working-class representation, Crane's decision to resist cultural and environmental particularism ran the risk of rendering the poor more, not less, aesthetic. Through this flattening of representation, Crane destabilized the fixed correspondences demanded by theories of biological and cultural heredity that pushed to the forefront the role of environment in the shaping of behaviour. What characterizes Crane's heroes therefore is not their now-clichéd search for identity or a culture of their own but the dangers implicit in the fact that they might actually find what they are looking for. The playgoers in 'Manacled' worship their cultural possessions as George's alcoholism gives him a sense of 
completeness and inclusion, but both ultimately lead to further, greater suffering. Crane's fictions therefore can be seen to provide an antidote to a version of Americanist literary canon-formation centred around identitarian notions of 'culture' and 'diversity' and are an important locus for the development of a more transnational, less nationally specific, literary criticism.

\section{Acknowledgements}

I would like to thank the Leverhulme Trust, the US-UK Fulbright Commission, and the US State Department for the generous funding that allowed me to complete this article.

\section{Notes}

I Richard Bentley also had a history of publishing US writers. The first English publication of Edgar Allan Poe's 'Fall of the House of Usher' was in Bentley's Miscellany.

2 George Stocking has argued that, more than Darwinism, by some way the most dominant theory of evolution, heredity, and adaptation in the transatlantic fin de siècle was a version derived from the work of the French naturalist, Jean-Baptiste Lamarck. Rather than locating evolutionary change and development within the remarkably longue durée of geographical 'deep time', Lamarckianism stressed how more immediate social and environmental factors could be registered by the organism and passed on within the space of a single generation. Stocking argues: 'The Lamarckianism of the fin de siècle American social science also had sources within the tradition of nineteenth century social thought itself. A number of its major figures among them Auguste Comte, Lewis Henry Morgan, and Herbert Spencer - were either implicitly or avowedly believers in the hereditability of acquired characteristics' (Stocking, I982: 240). In Crane's own moment the dominance in social scientific and literary circles of Herbert Spencer (a scion of ideas of Lamarckian heredity) ensured the continued presence of Lamarckianism in the late-nineteenthcentury scene long after the academic acceptance of Darwinian evolution.

3 Boas' critique of 'independent invention' developed out of a public battle the young anthropologist had in I887 with Otis Mason, the then-curator of exhibits at the Museum of Natural History in New York. In response to the desire to reorganize the ethnological exhibits at the museum, Mason and Boas disagreed over the reasons why different peoples, divided by geography, frequently developed similar kinds of tools to deal with everyday life. Mason argued that all human societies develop along the same pattern outlined by Lewis Henry Morgan in his work Ancient Society (I877) from 'savagery' to 'barbarism' to 'civilization' and that each period was marked by the development of specific tools, starting with rudimentary hammers through to bows and arrows and finally machines. By contrast, Boas saw human civilization as defined by the constant flow of ideas between peoples (a process of continual borrowing) that was an effect of a long human history of trade and empire. Unlike Mason, Boas favoured dioramas and exhibits that showed how the tools were situated in their specific contexts, i.e. he favoured use value over an evolutionary theory of progressive development; see Stocking, I989.

\section{Bibliography}

Althusser, Louis. 1984. Essays on Ideology. London: Verso.

Arnold, Matthew. 2006. Culture and Anarchy. Oxford and London: Oxford University Press.

Barrish, Phillip. 200I. American Literary Realism, Critical Theory, and Intellectual Taste, I880-I995. Cambridge: Cambridge University Press.

Brace, Charles Loring. I872. The Dangerous Classes of New York and Twenty Years' Work among Them. New York: Wynkoop and Hallenbeck.

Briggs, Charles L. 2005. Genealogies of Race and Culture and the Failure of Vernacular Cosmopolitanisms: Rereading Franz Boas and W.E.B. Du Bois, Public Culture, I7(I): 75-100. 
Crane, Stephen. 1984. Prose and Poetry. New York: Library of America.

Elliott, Michael A. 2002. The Culture Concept: Writing and Difference in the Age of Realism. Minneapolis: University of Minnesota Press.

Evans, Brad. 2005. Before Cultures: The Ethnographic Imagination in American Literature, I865-1920. Chicago: University of Chicago Press.

Gandal, Keith. 1997. The Virtues of the Vicious: Joseph Riis, Stephen Crane and the Spectacle of the Slum. New York and London: Oxford University Press.

Geismar, Maxwell. 1953. Rebels and Ancestors: The American Novel, I890-1915. Boston: Houghton Mifflin.

Howells, William Dean. 2002. A Hazard of New Fortunes. New York: Random House, Inc.

Kaplan, Amy. 1988. The Social Construction of American Realism. Chicago and London: University of Chicago Press.

Levine, Lawrence W. I990. Highbrow/Lowbrow: The Emergence of Cultural Hierarchy in America. Cambridge, MA and London: Harvard University Press.

Michaels, Walter Benn. 1995. Our America: Nativism, Modernism and Pluralism. Durham, NC and London: Duke University Press.

Monteiro, George, ed. 2009. Stephen Crane: The Contemporary Reviews. Cambridge: Cambridge University Press.

Morgan, Lewis H. I877. Ancient Society; or, Researches in the Lines of Human Progress from Savagery to Barbarism to Civilization. New York: Holt and Company.

Murphy, Brenda. I98I. A Woman with Weapons: The Victor in Stephen Crane's George's Mother. Modern Language Studies, II (2): 88-93.

Peirce, Charles Sanders. I878. How to Make Our Ideas Clear. Popular Science Monthly, I2 January. Available at: <http:/www.peirce.org/writings/pirg.html> (accessed July 25, 20I3).

Pittenger, Mark. I997. A World of Difference: Constructing the Underclass in Progressive America. American Quarterly, 49(3): 26-65.

Riis, Jacob A. [1890] 20I0. How the Other Half Lives: Studies Among the Tenements of New York. Cambridge, MA and London: Belknap Press.

Stocking, George W. 1982. Race, Culture and Evolution: Essays in the History of Anthropology. Chicago and London: University of Chicago Press.

Stocking, George W. I989. A Franz Boas Reader: The Shaping of American Anthropology, I883-I9II. Chicago: University of Chicago Press.

\section{Notes on contributor}

Michael J. Collins is a lecturer in American literature at the University of Kent. He also serves on the Executive Committee of the British Association for American Studies.

Correspondence to: Dr Michael Collins, School of English, Rutherford College, University of Kent, Canterbury CT2 7NX, UK. Email: m.j.collins@kent.ac.uk 